\title{
Vernacular architecture as a model for contemporary design
}

\author{
E. Creangă ${ }^{1}$, I. Ciotoiu ${ }^{1}$, D. Gheorghiu ${ }^{2} \&$ G. Nash ${ }^{1,3}$ \\ ${ }^{1}$ Faculty of Architecture, Spiru Haret University, Romania \\ ${ }^{2}$ Faculty of Decorative Arts, University of Art, Romania \\ ${ }^{3}$ Department of Archaeology and Anthropology, University of Bristol, UK
}

\begin{abstract}
The quest for a deeper approach of contemporary architecture to nature sometimes conceals the achievements of the past. Vernacular architecture is, by its definition, aim and structure, the most integrated architectural form in communion with the environment. Two important traces of vernacular architecture can be resources for contemporary architecture: the deep respect and perfect communion with the natural environment the perfect relation and understanding of users needs. The result of a complex balance between material, shape and natural context, vernacular architecture could become an extremely useful model of inspiration for the present. From the intimate and personal experience with the wooden and wattle and daub architecture of South Eastern Europe, we noticed that the mentioned triad created very efficient eco-design outcomes that could be used today as models to generate an architecture closer to nature. This paper will describe a series of case studies of vernacular architecture from different zones of the Carpathians and the Danube area, which could function as models for an eco-architecture model. Modern perspectives on the mentioned values include a new approach of specialists and communities, having as a purpose the understanding and integration of vernacular experiences and values in today's projects in order to enable architects to be an active part in plural-disciplinary teams, to promote their responsibility to conserve and valorize built and landscape heritage and the re-use and integration of existing buildings, technologies and skills in contemporary design.
\end{abstract}

Keywords: clay, adobe, wattle and daub, vernacular architecture, eco-architecture, education, cultural models. 


\section{Age old materials - new uses and technologies}

Traditional building materials, such as timber, stone and clay, are undergoing a revival in that they offer sustainability where the more labour intensive and costly materials, such as (reinforced) concrete, fibreglass, glass and steel, are unrealistic in terms of budget (Buchanan [5]; Keddie and Cleghorn [14]; Parry [24], Spence and Cook [26]). The large scale use of traditional building materials comes at a time when carbon footprinting, along with affordability, are becoming a necessary option, especially in those areas of the world where dwindling natural resources are becoming a cause of concern. Much of the technology and material properties used in traditional building construction have their origins with the first farmers, some 10,000 years ago, and little has changed in terms of technological input since this time. People still construct buildings using clay, timber and stone, however the way these [raw] materials are applied entails many years of research, experimentation and alloying with other materials. Indeed, clay products such as brick still use the same processes of extraction, production and use, albeit on a more industrial scale. At Stewartby in Bedfordshire, England up to 18 million bricks were manufactured each week during the 1970s and 1980s when brick production in Britain was at its peak (Nash [22]). At this time 24 Hoffmann Kilns were in operation. The use of clay as a building material is a world phenomenon and like food production, is arguably an essential and sometimes a finite resource (e.g. Bonner [3]; c.f. Zhang Kunyuan [28]). In this paper we wish to briefly highlight a number of ancient and historical examples that clearly show the durability and tactile nature of our most basic of raw material - clay. Using the archaeological and historical records, along with an experimentation project at Vadastra in southern Romania, we will advocate the remarkable qualities of the traditional uses of clay and suggest that in an economic climate of sustainability this material, along with timber and stone, may provide some of the answers to the pressure of providing affordable and eco-centric housing and a return to Romania's local/regional rural vernacular.

Clay is a natural material that is malleable, composed primarily of fine grained [platelet] minerals and can be worked in many ways, achieving many architectural and structural outcomes (e.g. ceramic brick and tiles, fig. 1). In the world of construction the technological processes to produce a clay product are relatively simple - the base clay, fire and water in varying quantities and temperature being the ingredients to achieve a desired result. Clay as a building material not only provides an aesthetic value to, say, a building vista but it can also provide the structural value a building needs in order to stand. Aesthetically, clay can be moulded and shaped to produce ornate tiling, facades and if refined and produced to a particular standard, terracotta ceramics can be made.

Clay is an argillaceous detrital sedimentary rock/soil that is gauged on its particle size - less than $1 / 256 \mathrm{~mm}$. Based on the moisture content - its plasticity, clay in its natural form can be colloidal and based on the geographic location and can contain all manner of sedimentary and igneous material. In terms of its 


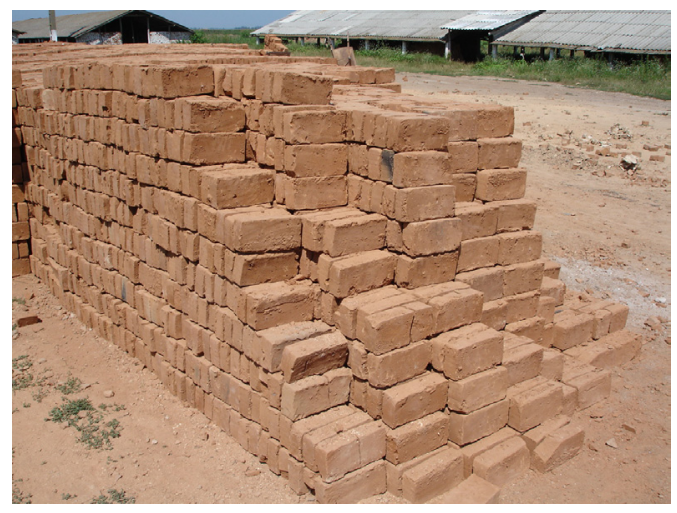

Figure 1: Bricks, bricks and more bricks: a southern Romanian brickworks in the Olt County, Vadastra commune.

atomic structure, clay is basically from a layer-lattice group of minerals, occurring as platy crystalline particulates. The geomorphological characteristics of clay, its accessibility and geographic range have, over the ancient past greatly influenced the design and structural capabilities of buildings. The plastic qualities of clay has allowed architects and builders over the millennia to include this remarkable substance in nearly all aspects of construction; used in the manufacture of bricks, floor, roofing, wall tiles and surface renders.

One of the most common products of clay is brick. Brick comes in many shapes and sizes and there have been many attempts to create a uniform sized brick (depending on what part of the world the brick is made). Due to the various design concepts through the ages brick still remains a most durable, tactile and diverse product. In Britain during the $19^{\text {th }}$ and $20^{\text {th }}$ centuries over 5,000 brick manufactures was each producing distinctive localized and regional brick types, usually based on clay geology and firing temperatures.

The earliest brick use occurs in domestic buildings from around 8,500 $\mathrm{BC}$ in the Upper Tigris at the settlement of Çayönü and in south-east Anatolia at Çatalhöyük (Hodder [12]). The first bricks to be fired using kiln technology date from the third millennium BC. Prior to this important innovation, bricks were sun-dried and made from mud (with varying constituents of clay, sand and silt). As opposed to other building materials, ancient builders realised the thermal qualities of brick; in that they absorbed and stored the heat of the sun in the day and released latent heat in darkness hours. It is probably from these most ancient of times that brick making becomes a craft specialization, employing generations of specialist [technologists] as well as unskilled labour. Knowledge of clay consistency/plasticity, extraction, clay preparation, firing and post-firing techniques would have been essential constituents for the success of the community (e.g. Brunskill [4]). Based on these base constituents we now turn to the buildings themselves, focusing on the rural vernacular of Romania. 


\section{Local materials and local traditions}

Result of a complex balance between material, shape and natural context, vernacular architecture is the most integrated architectural form in communion with the environment. As vernacular buildings are always realized with a direct participation of the first owner, they constitute the expression of practical and spiritual needs of each community, sharing same values systems. Synthesis of centuries of life experiences and building traditions, vernacular architecture is a synthetic and symbiotic harmony of individuals, community and the built environment, fig. 2 .

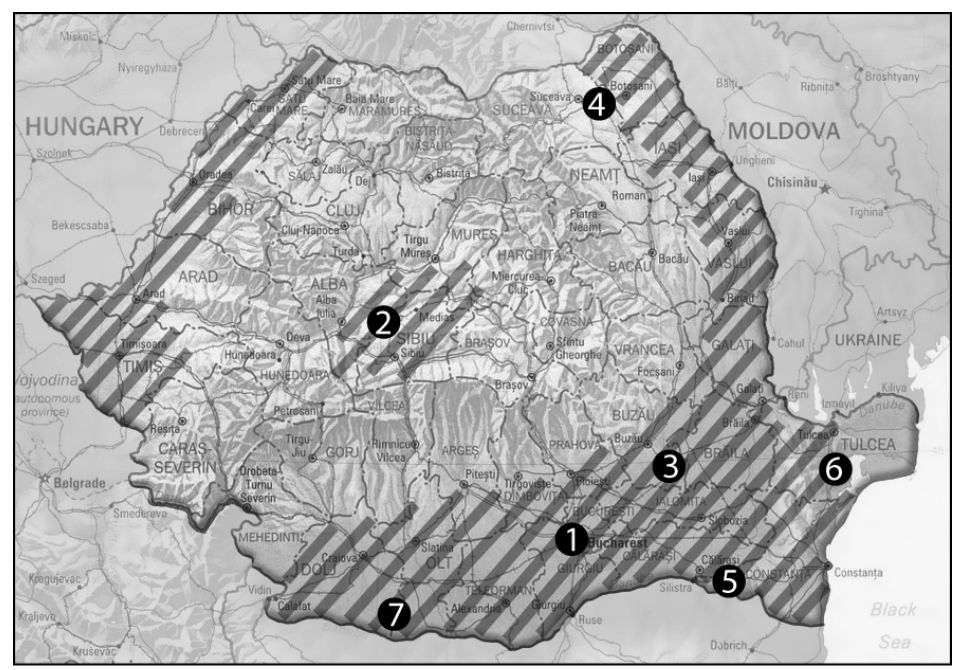

Figure 2: Map of Romania showing the areas with clay architecture and the sites cited in the text. 1 Bucharest, 2 Dumitra, 3 Rusetu, 4 Dumbraveni, 5 Ostrov, 6 Jurilovca, 7 Vadastra.

One of the most relevant values of the Romanian architectural heritage is, certainly, rural vernacular architecture. Characterized by an impressive unity in diversity, expressing a deep participation of the owners in the processes of creation, according materials and techniques to the needs for use and to the landscape, the richness and variety of rural vernacular heritage was the resource for a network of 17 open-air museums in Romania, realized in the last 70 years. Started in 1936, "Dimitrie Gusti" National Village Museum in Bucharest, the most frequented museum in Bucharest, receiving about 200,000 visitors by year, offers to its visitors 48 houses and farms, 4 churches, 20 technical installations brought from all districts of the country. The oldest monument dates from the $17^{\text {th }}$ century, and the newest from the beginning of the $20^{\text {th }}$ century.

Wooden architecture, earthen buildings, even one stone house - elements of Romania's very rich vernacular and ethnologic heritage - are exposed in Village Museum's open-air collection of monuments and constitutes a great architectural 


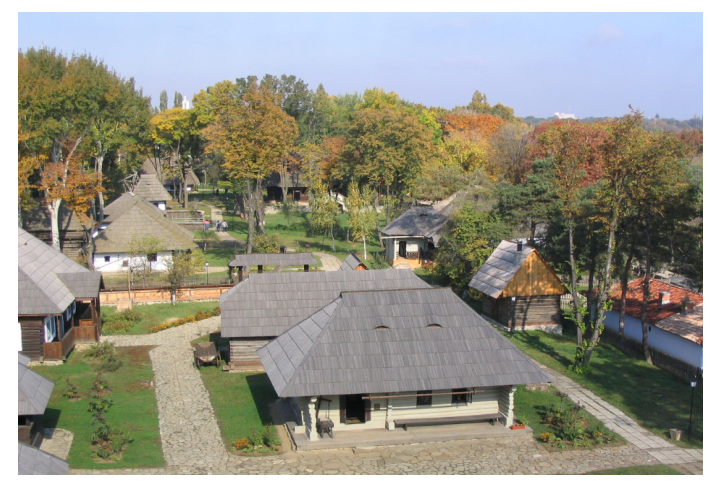

Figure 3: "Dimitrie Gusti” National Village Museum general view.

resource. This visual expression of the vernacular is partly supported by its invaluable document archive and educational support for architects and other specialists in the field. Main building materials and techniques can become study-cases concerning experiences in transmitting ethnological heritage values, especially at a localized and regional level.

Used in the last 4-5 millennia in lessoid areas, earth buildings were the main vernacular architecture solution, covering about $25 \%$ of Romania's surface. Five monuments of the "Dimitrie Gusti" National Village Museum ("DG"NVM), from Transylvania, Vallachia, Moldavia and Dobroudja, can be analyzed as examples of earthen structures (www.patrimoniu-etnologic.ro [27]), [29].

The Transylvanian house of Dumitra, Alba County, dating from the beginning of the $19^{\text {th }}$ century is built on oak forks (interconnecting [structural] timber blades) out of wattle coated with clay and represents a single-storey rural dwelling, fig. 4. This building has a high pitched roofing frame covered by a straw thatch tied together by osier twigs. The pitch is considered steep in order that rainwater will not penetrate the roof or internal spaces. Similarly, the lower pitch of the roof overhangs the elevations in order to keep the elevations dry. The elevation stands on a stone plinth, again preventing moisture from penetrating the timber uprights, fig. 5 .

The grange of Ruşețu-Buzău County originates from a village lying in the north-eastern part of the highest plain in Romania and was built at the latter end of the $19^{\text {th }}$ century. The primary building materials used was wattle and daub panelling that was supported by robinia forks stuck into the ground. The timber work comprised simple or double skeleton of laths nailed to posts, which are called "supports", or to short wooden "studs"; these too were buried into the ground. The wooden structure is covered by clay render (mixed with water). One or two layers of bonded stone, forming a plinth were placed at the foundation level, fig. 6 .

The County of Suceava lies in the north-eastern part of Moldavia and from this region is the house of Dumbrăveni originates, fig. 7. This building was built in the $19^{\text {th }}$ century using the technique of the oak forks which support secondary timber framework, fig. 8. The external panels were infilled with 


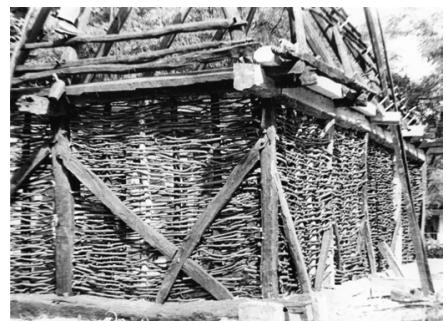

Figure 4: Horizontal wattle and timber, Dumitra.

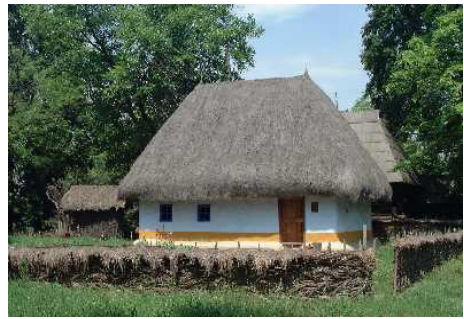

Figure 5: House from Dumitra, Alba County in "DG"NVM.

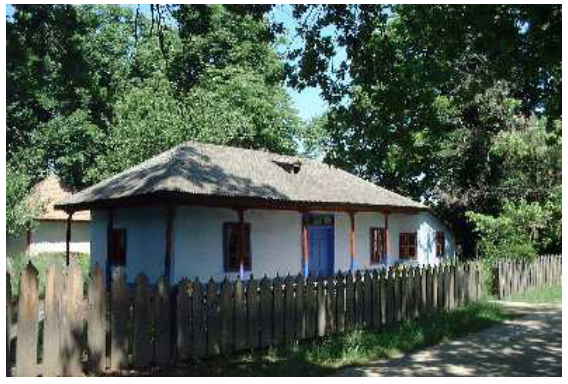

Figure 6:

$$
\begin{aligned}
& \text { Grange from Ruşețu } \\
& \text { Buzău County in } \\
& \text { "DG”NVM. }
\end{aligned}
$$

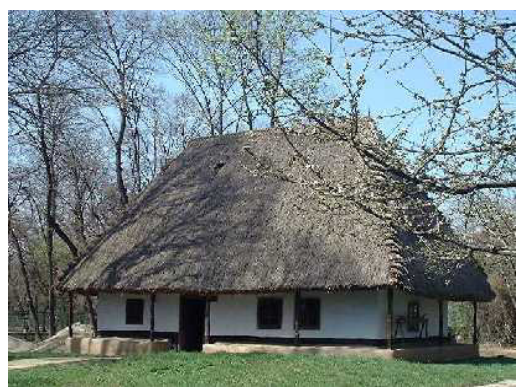

Figure 7:

from

Dumbraveni Suceava

County in "DG"NVM.
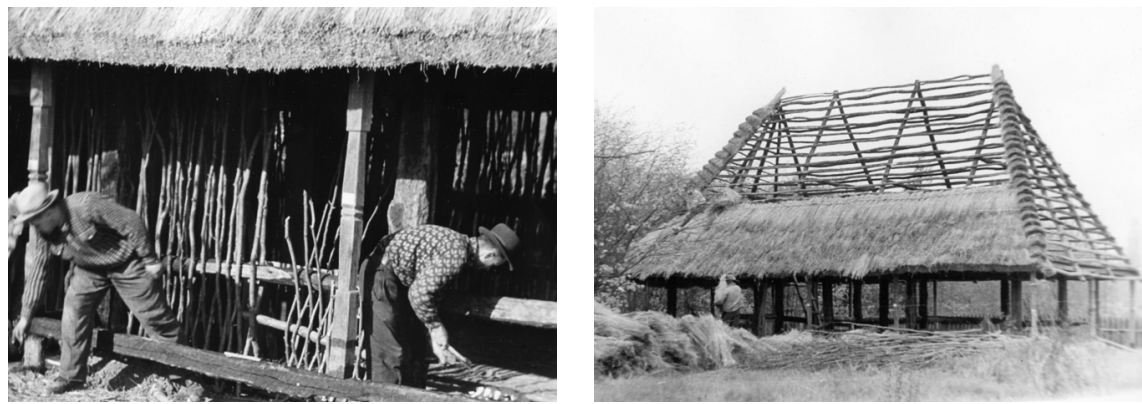

Figure 8: Vertical wattle and Figure 9: The building of the timber, Dumbrăveni. roof, Dumbrăveni. 


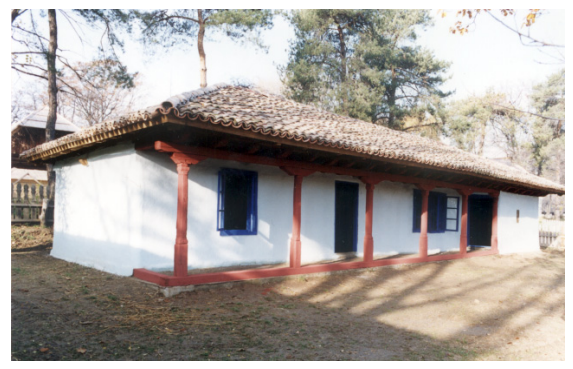

Figure 10: House from Ostrov, Constanta County in “DG”NVM.

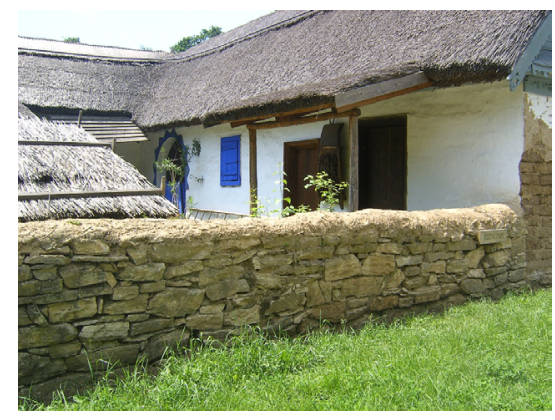

Figure 12: The annexes of the house, Jurilovea in "DG"NVM.

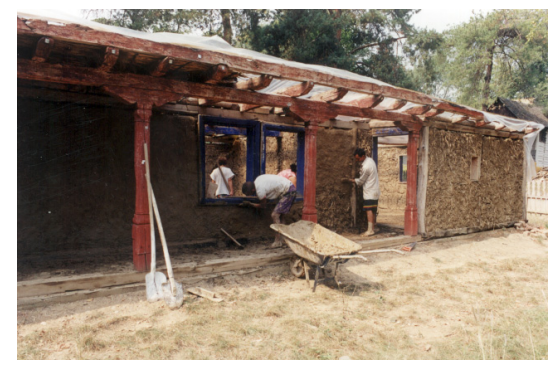

Figure 11: Wattle and daub structure, Ostrov.

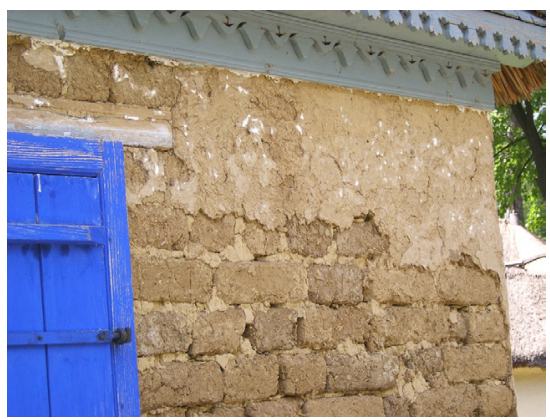

Figure 13: Detail of the house, Jurilovca.

wattle and daub (comprising clay and straw). The four-sided roof is covered in "jupchi”, overlapped sheaves of rye, fig. 9.

The house of Ostrov - Constanța County is typical of the old Romanian villages that contained granges, especially those sited along the River Danube, fig. 10 .

Built of hornbeam oak forks and initially infilled with wattle and daub panelling, fig. 11, the elevation was coated in a clay render. The house has a roof with four gently sloping sides covered in tiles.

The grange of Jurilovca (near Razelm Lake, Tulcea County) was built in 1898. The house, and the annexes - the cave, the shed, the stable, the fish smoking house, fig. 12 - are all built of adobe, with pediments at both ends and reed covering, fig. 13.

As "Dimitrie Gusti" National Village Museum is an open-air collection of vernacular monuments, restoration activities constitute an essential field in transmitting traditional values. Conservation and restoration phases are realized by craftsmen invited from the same geographical area where the building originates, using natural materials and respecting traditional local and regional 
construction techniques. All activities on monuments are supervised by curators, conservators and architects. In addition, artisans and craft specialists are working, demonstrating and teaching, simultaneously to visitors and to students, architects, other specialists, the importance of regionality of Romania's building vernacular.

Special attention is given to educational partnerships with schools of architecture, which have every year use the museum resources for practical courses, interior design and the document archives. Starting with the first steps in architecture, student's activities, in particular vernacular values have a special place and are extended for those who are interested in elective courses or other activities; as witnessed with projects run by multi-disciplinary teams in several areas of the country; one of these areas of intensive and systematic research is Vadastra in the Olt region.

\section{Age old methods, local contexts}

The technique of using clay in the construction of dwellings (as rammed earth, adobe, and adobe brick) in villages of southern Romania began to be replaced with methods of construction of urbanism, commencing before World War II (Minoiu et al.: $161 \mathrm{ff}$. [20]). Using traditional materials such as clay and wood was thus restricted to household annexes, which were constructed in the wattle and daub technique, usually supported by timber-framing (Minoiu et al.: $108 \mathrm{ff}$., [20]).

Professor Dragos Gheorghiu conducted a study of the revitalization of the technological tradition of vernacular wattle and daub architecture in the village of Vadastra, southern Romania between 2003 and 2007. The study was possible due to a research project on the traditional ecological habitat (Gheorghiu [7-9]), funded by two grants from the Romanian Ministry of Education and Research (CNCSIS Grants 1612 \& 945).

Beside the experimental research of the traditional constructions the project allowed the study of the way a contemporary rural community could return to the traditional ecological building techniques, using local [quarried] clay and other local material resources.

Vadastra village with its 1,643 inhabitants is situated in Olt County, in the southern Romanian Plain, on the loess northern terrace of the River Danube (Logofatu: 8 [16]). The entire wooded area of the south of this region has been largely cleared, wood being a very scarce commodity today. Bricks were produced by each family at the outskirts of the village with clay extracted from the local river terrace, and burned in pyrotechnic truncated pyramid [kiln] structures (Carlton: 22 [6]).

Today the architectural materials of the village comprises mainly of bricks and concrete, and no longer uses clay except for those households with annexes; though, a generation ago, most houses were made of timber, wattle and daub (Ghinoiu [10]), and only the Mayor's building was built of brick. Compared to the vernacular architecture of a century ago, the contemporary architecture of the village is made with materials that do not preserve any traditional or ecologic 
character, being only determined by the owner's exhibition of prestige; the vernacular of this region is thus somewhat lost.

In this context, the re-introduction of ecologic traditional technology using clay for the dwellings was primarily a problem of explaining the advantages of an ecologic architecture to the village population. The action began, indirectly, with an ethno-archaeological and experimental archaeology study of the dwelling process in this area in the past, which is summarized below.

Besides the experts and students participating in the experiment of construction, a group of villagers were involved. We considered this local input essential in understanding the seasonal needs and aspirations of a community governed by the importation of building materials and a potential lost generation of people who had largely forgotten the available resources such as the terrace clays.

During the three annual campaigns, three houses each measuring c. $3 \times 8 \mathrm{~m}$ and a semi-subterranean house of $2 \times 5 \mathrm{~m}$ were constructed, all being specific for this region and ranging in technological achievement from prehistoric to modern times.

All these buildings had a resistant acacia wood structure and wattle panelled walls, using twigs of mulberry and poplar, which are the only types of trees that still grow in this area.

The experiments started with the test of the foundation ditches, a construction method for earthen architecture used from prehistory to the modern age in the region of Oltenia (Minoiu et al.: 163 [20]). The ecological benefit of this type of structure in that it involves only local soil and organic materials, and preserves well over a long period, especially in wattle and daub buildings.

Following the erection of the timber frame and the wattle panelling, then began the operation of fixing the clay on the wattle walls, fig. 14, 15, which required three days of work for a group of 3-5 persons. The finished surfaces of the inside and outside walls and ceiling were left to dry for two days before the thatching of the roof using reed commenced. Numerous repair interventions were needed for correcting the cracks due to the shrinking of the clay that had been fixed to the various sections of the wooden structure. The final phase of work included the fixing of a thin layer of render made of clay mixed with cow dung which covered the elevations (McDermott: 303-4 [18]).

The first building was preserved in order to analyze the rate of denudation from weathering processes and human action. Our first ecological question was to find that if the walls were well compacted when fixing the structure of wood and straw and to see if their resistance was similar to that of brick structures. The continental climate of Vadastra region, with average summer temperatures of 25 ${ }^{\circ} \mathrm{C}$, which can rise sometimes to $39^{\circ} \mathrm{C}$ in August, and relatively low rainfall, favours wattle and daub architecture. Our experiments at Vadastra proved that the buildings were very cool inside during the summer.

All local materials of construction were collected from an area of $1 \mathrm{~km}$ square around the site, and the construction operations did not require specialized tools other than those used for gardening. The other houses, which were left to the 


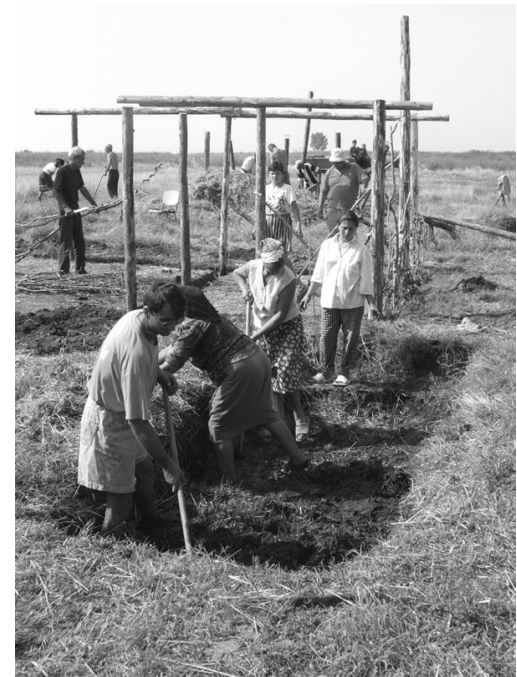

Figure 14: Pit for the preparation of adobe, Vădastra, 2005 .

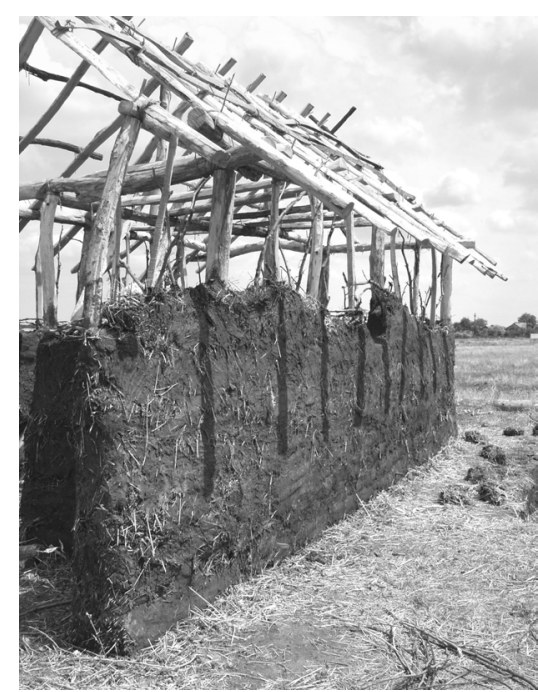

Figure 15: Wattle and daub house, Vădastra, 2003.

weathering process, have shown they were completely biodegradable following the recycling of their massive wooden frames.

The project undertaken in Vadastra village was arguably a process of cultural education held on two levels: as an ecological education, students and as a folk culture, convincing villagers that their local resources may allow the development of an ecological technology of construction by applying the methods used by previous generations of villagers.

As confirmed by the archeological and ethnographic data, clay alone or in combination with other building materials or substances, has been for almost 5 millennia the fundamental building material for the Romanian Plain area and for most of Europe. But, how can we explain this long-term persistence of a technological tradition? Besides the fact that it was the most easily suppliable material in lessoid soils areas (mainly in the warm climate areas), it had the following advantages: easy extraction, easy preparation, easy possibility of creating composite and reinforced materials, thermal efficiency, recyclability, biodegradability, resistance and sustainability under the action of natural factors, permissivity in developing repair or expansion operations of certain existing constructive elements (Minke [19]).

Considering the challenges of contemporary society, successfully passing the test of time, the qualities of clay as a building material may be ironically found in buildings that house most of the low-income population. These approaches of low-cost, low-energy materials such as clay surely meets the constraints that are firmly set within the raw material crisis, the energetics crisis and the fight against global warming and other ecological-related issues. 


\section{Earth architecture as ecological architecture}

The extensive use of earth in various parts of the world (see Maniatidis and Walker [17]; Morton [21]), as well as in Romania, to create a sustainable architecture, is due to some qualities, which qualify it as the contextual building material.

We will present below a few of these qualities that demonstrate also its ecological character.

The first is the total recycling of the material, because the "waste by-products and defective products can be returned to the start of the production cycle and reused" (Little and Morton [15]). When compared with the other building materials employed in contemporary architecture, earth produces the less pollution, when extracting, preparing and recycling.

Consequently, the second quality is that of a low carbon emission, earth dried bricks necessitating only $440 \mathrm{KWh} / \mathrm{m}^{3}$, compared with ceramic bricks, which consume $1300 \mathrm{KWh} / \mathrm{m}^{3}$ (Little and Morton [15]).

The third quality is the solar gain, obtained by orientation and thermal mass. These two ecological commandments were amply used in the Romanian vernacular earth architecture. Since the large majority of the houses were built with the main façade facing south, the new buildings replacing the old will not disturb the spatial orientation within the households. The intervention of contemporary architects could be to build a series of annex rooms on the northern facades to lower the thermal loss. A revival of the spirit of vernacular architecture would be the continuation of the tradition of the porch (Ro: prispa, pridvor) south oriented, whose roof protects the façade wall from the summer sun, but allowing the solar exposure in wintertime. By transforming this space into a sun lounge during the cold season one can maximize the glazing on the south façade. Such architectural solution was in fashion until the early $19^{\text {th }}$ century in urban buildings inspired from folk architecture (Joja [13]), but was forgotten later.

The exploitation of the thermal mass in earth architecture is achievable by emphasizing the thickness of the walls, and by designing the shape of the roof covering the porch, in such way as to allow large areas of the south façade to be exposed to winter sunlight.

A fourth quality is the possibility to improve its properties by adding various binders.

To improve the technologies of building with earth (i.e. mud wall, rammed earth (Fr. pisé), earth bricks, compressed earth blocks, earth infill in timber frame construction, earth plasters, see Little and Morton [15]), one can utilize diverse organic or mineral additives (Minke: 41[19]; North [23]) to stabilise earth (see also Adam [1]; Sharif-Zami and Lee [25]).

All the additives or stabilisers, can increase the material durability and strength as well as the embodied energy (Little and Morton, [15]). However, some stabilisers like cement decrease the qualities of the prepared material, to cite the ability of acting as a humidity buffer of the stabilized earth (see North [23]). 
This is the reason why we recommend using as additives the recycled subproducts of the local households or the sub-products of the local industries, all these possessing ecological qualities.

Tests demonstrate that the mix of cut straw fibres diminishes the compressive strength (see Minke: 47, Table 4.20 [19]), therefore rammed earth seems the best material to be used for earth buildings with more than one floor.

The fifth quality is the thermal performance of the earth; for example, a rammed earth wall without stabilizers equals the thermal performance of a solid ceramic brick wall (Minke: 31 [19]).

The sixth quality of earth compared with other building materials is the good absorption of humidity. When comparing the degree of humidity absorption of earth walls $\left(300 \mathrm{~g} / \mathrm{m}^{2}\right.$ for a $1.5 \mathrm{~cm}$ mud layer; Minke: 16 [19]) with ceramic bricks (6 to $30 \mathrm{~g} / \mathrm{m}^{2}$ ) or plaster $\left(26\right.$ to $76 \mathrm{~g} / \mathrm{m}^{2}$ ) one can observe the quality of the material to balance the humidity in a built space.

\section{Concluding remarks: cultural modelling}

What could be the conclusions of a project that considers returning to the use of earth in the Romanian village architecture?

As suggested above, there has been a millenary tradition in using this material that has survived through the modern age and is still working in certain peripheral areas of the country; our rural vernacular.

Our approach aims at promoting an educational model as well as a cultural model, fig. 16, 17.

We might demonstrate that in the case of a sustained social action, some mindsets may change and some village people might agree with an environmental-friendly design using earth in designing certain types of houses or figurative [principal] buildings, such as museums of the tradition or archaeoparks. Romanian architects have already started to think about the concept of an ecological built heritage using earth and several of these include:

- $\quad$ project for the development of a traditional museum village in Radovanu commune, Ilfov County - author: Faculty of Architecture of Spiru Haret University

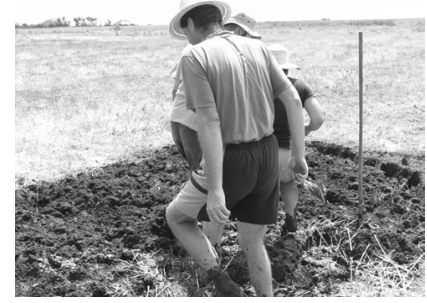

Figure 16: Students preparing the Figure 17: Villagers from Vadastra adobe, Vadastra 2003.

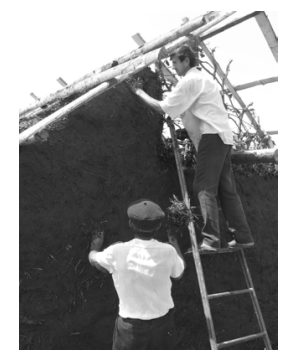

building an archaeopark, Vadastra 2006. 
- $\quad$ catalogue with projects of houses, and bed \& breakfast facilities for the Danube Delta (protected area) - author: IGLOO ARCHITECTURE office.

In order to respond to expanding needs of specialists in conservation, as well as in multi-disciplinary planning practices, able to transmit the cultural values of good architecture, architectural education has to include modules that aim to teach and develop student's understanding of the value and complex potential of the inherited built environment.

Spiru Haret University, School of Architecture is the first private school of architecture in Romania, accredited by the Romanian Ministry of Education and Research. Its curricula include theoretic and practical courses for vernacular architecture, architecture and sustainable development, monument-restoration and the built heritage. Many of these courses, as well as drawing and perspective practical courses, interior design documentation, are using as documentary support the resources of the Dimitrie Gusti National Village Museum heritage. Students have to analyze the values and potential of the built heritage, in order to reflect on critical criteria and creative practices related to regeneration as essential component of sustainability. This internationally important museum site is really a starting point for any would-be architect from this part of Europe.

Romanian rural vernacular architecture is still, in the $21^{\text {st }}$ century, a live element, which expresses, in a really complex way, the creativity and specificity of traditional building systems. The vernacular buildings that are in good state of preservation, dispersed all over the country, constitute the support of a really dynamic development of rural tourism, agri-tourism, eco-tourism, as sustainable tourism components. These forms of tourism can become alternatives for rural vernacular architecture preservation. In addition and in many ways extending beyond the constraints of tourism per se, the rural/traditional vernacular promotes an identity with the people who work and live within these sometimes ethnically diverse communities. Taking these points into consideration, we now briefly conclude with our vision for the future. At an educational level we have started the instruction of the student architects and designers in the spirit of understanding the ecological features that include a local tradition of vernacular architecture and of reintroducing the traditional materials in the architecture plan. Thus, the workshop themes for the $1^{\text {st }}$ to the $4^{\text {th }}$ years at the Faculty of Architecture, Spiru Haret University include elements of ecology, inspired by local/regional vernacular architecture.

The education of the young architects may enable the revitalization of the ecological spirit of local vernacular architecture and of the $3^{\text {rd }}$ millennium AD architecture. Based on the ancient archaeological record, the historic record and the experimentation programme at Vadastra we are sure lessons can be learned.

\section{References}

[1] Adam, E.A., 2001, Compressed Stabilised Earth Block Manufacture in Sudan, unesdoc.unesco.org/images/0012/001282/128236e.pdf 
[2] Becky L., and Morton, T., 2001, Building with earth in Scotland: Innovative design and sustainability, www.scotland.gov.uk/Resource/Doc/ 156686/0042109.pdf

[3] Bonner, R. 1984. Better Burnt Bricks, Action-Aid Kenia, Nairobi.

[4] Brunskill, R.W. 1990. Brick Building in Britain. Victoria Gollancz \& Peter Crawley.

[5] Buchanan, W. 1985. Labour Intensive and Small Scale Brickmaking, UNIDO, Vienna.

[6] Carlton, R., 2002, Experimental open firing of locally sourced clays at Vadastra, South-East Romania, Gheorghiu, D. and Andrews, K (eds.), Experimental Pyrotechnology Group Newsletter, pp. 22-24.

[7] Gheorghiu, D., 2005, The Archaeology of Dwelling. Theory and experiment, Editura Universitatii Bucuresti, Bucharest.

[8] Gheorghiu, D., 2007, Material, spatiu, symbol. Note despre tehnologia de constructie si deconstructie a locuintelor Calcolitice din sud-estul Europei, Anuarul Muzeului Etnografic al Transilvaniei, pp.364-377.

[9] Gheorghiu, D., 2009, The Lower Danube Chalcolithic megaron house with internal column: The technology of building interpreted through experiments, pp. 1 -10. In Ayan, X., Manana, P. si Blanco, R. (eds.), Archeotecture: Second floor. Papers from the archaeology of architecture at the EAA Meetings in St. Petersburg (2003) and Lyon (2004), British Archaeological Reports, International Series 1971, Archaeopress, Oxford.

[10] Ghinoiu, I. (ed.), 2003, Atlasul etnografic roman, Habitatul, vol. 1, Editura Academiei Romane, Bucharest.

[11] Hodder, I. 1990. The Domestication of Europe. Blackwell Press, London.

[12] Hodder, I., 1998. Çatalhöyük, Anatolian Archaeology, 4, 8-10

[13] Joja C., Sensuri şi valori regăsite, Eminescu, Bucharest, 1981.

[14] Keddie, J. \& Cleghorn, W. 1980. Brlck Manufacture in Developing Countries, Scottish Academic Press Ltd., Edinburgh

[15] Little, B., and Morton, T., 2001, online, Building with earth in Scotland: Innovative design and sustainability, www.scotland.gov.uk/Resource/Doc/ 156686/0042109.pdf

[16] Logofatu, C., 2007, Monografia comunei Vadastra-Olt, Arves.

[17] Maniatidis, V., and Walker, P., 2003, A Review of Rammed Earth Construction for DTi Partners in Innovation Project 'Developing Rammed Earth for UK Housing', http://people.bath.ac.uk/abspw/rammedearth/ review.pdf

[18] McDermott, D., 2007, Mud-plaster, pp.303-304. In Oliver, P. (ed.), Vernacular architecture of the world, Cambridge University Press, Cambridge.

[19] Minke, G., 2006, Building with earth. Design and technology for a sustainable architecture, Birkhäuser, Basel, Berlin, Boston.

[20] Minoiu, M.R., Ciobanel, A.I., and Budis, M., 2005, Locuinta, In Ghinoiu, I. (ed.), Habitatul, Vol. 1, Oltenia, Editura Etnologica, Bucharest.

[21] Morton, T., 2006, Feat of Clay. Materials World, pp 2-3. 
[22] Nash, G.H. 2009. Stewartby Brickworks, Bedfordshire Monitoring Programme for two Hoffman Kiln Buildings (CK1\& CK3). Report presented to English Heritage and Hanson Building Products UK. Report No. 402.0027.00177.

[23] North, G., [nd.], Mud Brick and Cob - Natural Earth Building and Stabilisers, www.ecodesign.co.nz/mudBrickCob\&Stabilisers.shtml

[24] Parry, J. 1979. Brickmaking in Developing Countries, Review prepared for the Overseas Division, Building Research Establishment, Garston.

[25] Sharif-Zami, M., and Lee, A., [nd], Contemporary earth construction in urban housing - stabilised or unstabilised?, www.gla.ac.uk/media/ media_129735_en.pdf

[26] Spence, R.J.S. \& Cook, D.J. 1983. Building Materials in Developing Countries, John Wiley \& Sons, Chichester.

[27] www.patrimoniu-etnologic.ro

[28] Zhang Kunyuan (ed.) 1988. Technology Manual on Claybricks in China, UNDP/ UNIDO Regional Network in Asia-Pacific for Low-Cost Building Materials Technologies and Construction Systems, Manila.

[29] xxx. Locuința sătească din România.1989, Studiu ICCPDC Bucharest. 